\title{
Reabilitação vocal em pacientes com doença de Parkinson: fatores interferentes $* * *$
}

\author{
Vocal rehabilitation in patients with Parkinson disease: \\ interfering factors
}

Denise Navarro Silveira* (de.navarro@ig.com.br)

Alcione Ghedini Brasolotto**

\begin{abstract}
*Fonoaudióloga. Especialista em Voz pelo Conselho Federal de Fonoaudiologia.

**Fonoaudióloga. Professora Doutora do Departamento de Fonoaudiologia da Faculdade de Odontologia de Bauru da Universidade de São Paulo.

***Trabalho Realizado na Universidade de São Paulo - Campus de Bauru.
\end{abstract}

Artigo de Relato de Caso

Artigo Submetido a Avaliação por Pares

Conflito de Interesse: não

Recebido em 18.08.2003. Revisado em 24.11.2003; 31.05.2004; 25.10.2004; 4.04.200.

Aceito para Publicação em 19.04.2005.

\begin{abstract}
Background: vocal rehabilitation of patients with idiopathic Parkinson disease. Aim: to describe the interfering factors in the vocal rehabilitation of five individuals with Parkinson disease and to present the modifications in the oral communication. Method: interviews and pre and post vocal treatment assessments were carried out using the Lee Silverman Voice treatment method (LVST ${ }^{\circledR}$ ). Results: articulation improvement was observed, as well as improvements in the vocal loudness and quality, generating satisfaction among the patients and family. Conclusion: the analyses of factors that contributed to the therapy process or made it difficult indicate aspects that must be taken into consideration to obtain effective results.
\end{abstract}

Key Words: Voice; Parkinson Disease; Voice Training.

\section{Resumo}

Tema: reabilitação vocal de pacientes com doença de Parkinson idiopática. Objetivo: descrever os fatores interferentes na reabilitação vocal de cinco indivíduos com doença de Parkinson e apresentar as modificações na comunicação oral. Método: foram realizadas entrevistas e avaliações pré e pós-tratamento vocal pelo método Lee Silverman Voice Treatment (LSVT ${ }^{\circledR}$ ) Resultados: observou-se melhora na articulação, intensidade e qualidade vocais, gerando satisfação em pacientes e família. Conclusão: a análise dos fatores que contribuíram ou dificultaram o processo terapêutico aponta os aspectos que devem ser levados em consideração para atingir resultados eficazes.

Palavras-Chave: Voz; Doença de Parkinson; Treinamento da Voz. 


\section{Introduction}

Parkinson's disease is a degenerative central nervous system disorder that mainly attacks the motor system. It does not have a known cause and it generally afflicts men and women alike after the age of fifty. It is one of the most common neurological conditions and, apparently, it is not genetic in nature (Nitrini and Bacheschi, 1991; Gamboa et al., 2001).

Parkinson's disease is a chronic and progressive illness; however, symptom evolution is generally slow. The characteristic symptoms are: tremors, muscle rigidity, akinesia, bradykinesia and posture alterations (Swinburn and Morley, 1997). Forrest et al. (1989) defined Parkinson's disease as basal ganglion function damage, manifested by movement deficits, including speech and movement initiation and extension limitations. The disease first affects the ability to initiate and coordinate complex motor tasks. As the disease progresses, the symptoms become more and more evident. As a consequence the activities the afflicted individual can carry out become increasingly limited, since the fine, global and oral motor performance becomes extremely compromised.

The rigidity is caused by the increased muscle tonicity or inflexibility. Unless controlled by antiParkinson medication, the rigidity shall always be present, and it shall increase during movement. It is responsible for the patient's facial expression that resembles a mask. Additionally, when tremors are present, they can be accentuated on one side of the body, and when they affect members, they can also afflict the head, neck, face and mandible. Bradykinesia, on the other hand, is characterized by a delay in movement initiation. This is caused by the delay in the brain to transmit the required instructions to the other parts of the body. When the instructions are received, the body responds slowly (Nitrini and Bacheschi, 1991; Swinburn and Morley, 1997).

From a speech language pathology perspective, voice, articulation and swallowing alterations can be commonly found due to the conditions associated with Parkinson's disease (rigidity and bradykinesia). These alterations can considerably compromise the Parkinson's individual's communication and feeding (Ramig et al., 1995; Ramig et al., 2001a; Cardoso et al., 2002; Schindler and Kelly, 2002; Oliveira et al., 2004).

Patient feeding begins to be jeopardized when dysphagia symptoms are present. Oropharyngeal dysphagia is one of the complications derived from Parkinson's and it is determined by food transportation damage resulting from the increase in oropharyngeal transit time and laryngeal mobility alterations (Volonte et al., 2002; Cardoso, 2003). It can also be associated with functional alterations in the lower esophagic sphincter (Leopold and Kagel, 1997), thus compromising these individual's nutrition and quality of life in the more severe cases.

Breath phonation and hoarseness are the most frequent vocal alterations encountered. There is an evident reduction in intensity, as well as reduced tonal range and articulatory imprecision. Male subjects revealed elevated modal pitch (Holmes et al., 2000; Gamboa et al., 2001). These vocal alterations can reduce oral communication effectiveness (Spielman et al., 2003) and can affect the social, economic and psychological well-being of patients with Parkinson's disease (Regnell, 2003). Patient vocal alterations have been attributed to incomplete glottic closure, a reduction in laryngeal muscle activation and synergy, muscle fatigue or atrophy, vocal fold movement or tension asymmetry, and vocal fold or respiratory muscle rigidity (Solomon and Hixon, 1993; Yuceturk et al., 2002). Speech and vocal alterations in individuals with Parkinson's disease have also been attributed to neurocognitive, neuro-affective or pyschomotor cerebral dysfunction (Ramig et al., 1995).

Traditional voice treatment for vocal alterations in Parkinson's subjects involves three different approaches: myotherapy, speech structure coordination and respiration. Treatment is normally given once or twice a week, with an emphasis on articulation, speed and prosody. However, only limited results have been obtained after this type of treatment (Ramig et al., 1995; Knoop et al., 2001; Monte et al., 2001). Therefore, a new vocal treatment method was developed starting in 1993 at the University of Denver in the United States. The Lee Silverman Voice Treatment $\left(\mathrm{LSVT}^{\circledR}\right)$ is a vocal treatment developed specifically for Parkinson's patients, which focuses exclusively on the voice. The method's main objective is to improve the quality of communication with an exclusive therapeutic emphasis on increasing vocal intensity. The treatment was developed to increase vocal intensity through an increase in phonatory effort, vocal fold adduction and respiratory support. In order to achieve this objective, the patient should recognize the need to increase 
loudness, feel comfortable with a stronger voice, and develop the ability to adjust the self-monitored loudness level. This method has revealed effective results in the short (Ramig et al., 1995; Baumgartner et al., 2001; Sharkawi et al., 2002) as well as the long term (Dromey et al., 1995; Ramig et al., 2001a; Sapir et al., 2002).

The objective of this study is to describe the factors that interfere in the voice rehabilitation of 5 subjects with Parkinson's disease and show the oral communication changes after treatment using the LSVT $^{\circledR}$ method.

\section{Method}

This study was analyzed and approved by the Ethics in Research Committee at the University of São Paulo - Bauru Campus, under protocol \# 459/ 02. All of the subjects involved consented to participate in this research and to the disclosure of results as per Resolution 196/96.

Five subjects with Parkinson's disease participated in this study. They were diagnosed with idiopathic Parkinson's disease, which was confirmed by a medical evaluation. All five subjects already presented vocal complaint. The participants were forwarded by the Bauru Parkinson's Nucleus and an otorhinolaryngologist.

The patients and family members first responded to an initial interview that aimed to define the participants according to disease or other health condition history, communication complaints, such as speech and voice, nutrition and the voice's influence on the subject's social life.

When treatment was finished, the participants responded to another interview with the objective of finding out if they observed any change in oral communication.

Audiology and otorhinolaryngology evaluations, including nasofibroscopy, were performed. The objective of the audiology exam was to verify the presence of any impediments to auditory monitoring, which could interfere in the voice. The videonasoendoscopy exam is a routine procedure prior to any vocal treatment, and for this intervention in particular, it is indispensable. The presence of laryngeal lesions is an exclusion factor for the patient who undergoes the therapeutic method chosen for this study. None of the patients revealed any laryngeal alterations that would counter-indicate the use of this method.

The patients underwent the Lee Silverman vocal treatment method. Vocal evaluations were carried out both before and after treatment concentrating on voice type, loudness, tonal range, articulation type, maximum phonation time and the potential capacity for intensity modulation.

The therapy and evaluation procedures were carried out at the Speech Language Pathology Clinic at FOB-USP.

The following materials were used: Sony MZR70 MD Recorder, HD54 Le Son Headset microphone, a stop watch, Instrutherm Dec-405 sound level meter.

Spontaneous speech and sequenced speech emissions were recorded for vocal evaluations.

The prolonged /a/, /s/ e /z/ speech sound emissions were recorded. The maximum phonation time was measured using a stop watch.

The sustained /a/ vowel emission in normal strong and weak speech intensities was requested to evaluate the potential capacity of modulation. A sound level meter was positioned 30 centimeters from the mouth during these emissions.

The patients remained seated throughout the evaluation period. The same recording posture was maintained both before and after therapy for each patient. The microphone was positioned ten centimeters from the mouth at a 45 degree angle.

The therapy program was comprised of four weekly visits. Each session lasted from 50 minutes to one hour. The sessions were held for four weeks, for a total of 16 sessions.

The treatment sessions included maximum phonatory effort tasks, such as maintaining a strong intensity /a/ vowel phonation for as long as possible. This was carried out for low and high pitched emissions for half of each session period. During the other half of the session, the patient was encouraged to use the increased phonatory effort in strong intensity speech production through linked speech training. Besides the treatment activities, the patient performed daily tasks at home. The increase in loudness was implemented through hierarchical speech tasks including words and phrases (week 1), sentences (week 2), reading (week 3 ) and conversation (week 4).

Patient treatment considerations

\section{Patient 01}

The patient demonstrated great interest in participating in the therapy during treatment and was very dedicated throughout all treatment sessions. However, as the patient himself reported, 
he frequently forgot to employ the strong voice at home. The patient's greatest difficulty involved his time schedule and it was impossible to establish a fixed therapy schedule. Besides vocal treatment, the patient was undergoing physical therapy, participating in the Bauru Parkinson's Nucleus meetings and even exercising his profession. His family was participative and interested in the vocal treatment, always seeking ways to help him and reporting on every success the patient had. According to the family, it was possible to notice the patient having an easier time to speak even during treatment and he was carrying on longer conversations with more people.

\section{Patient 02}

The patient demonstrated much interest in the therapy. She reported that her voice was weak and many times her speech was too quick. She did not always have the patience to repeat herself so the others could understand her. The patient participated in every session with great disposition and interest. She also participated in the Bauru Parkinson's Nucleus meetings and had physical therapy sessions. She is a very active person and performs diverse activities around the house. Her family did not get involved in the treatment in the sense of accompanying the patient or in showing any interest in the therapeutic method. However, according to the patient, everyone helped her perform the proposed exercises at home and they told her that her voice was stronger and easier to understand.

\section{Patient 03}

The patient demonstrated interest in participating in therapy, however he had much difficulty in understanding what was being proposed during therapy. He demonstrated a slight degree of dementia associated with Parkinson's. The patient was sleepy most of the time during the therapy sessions, and sometimes he even fell asleep while performing the exercises. It was necessary to adapt the thrust technique ${ }^{1}$ associated with the strong voice in order to keep the patient more active. However, his apathy was too great. Even with intense stimulation on the part of the therapist, the patient demonstrated several wandering moments. His wife said he did not perform the exercises on a daily basis at home. He did not undergo physical therapy treatment although his compromised locomotion required it. The patient lived alone with his wife. Although she was very interested in helping him, she had health problems and she was not always able to accompany him or to encourage him to use the strong voice. According to his wife, there was vocal improvement in the patient at the beginning of the treatment program; however, she no longer noticed any difference at its conclusion. She did report though that the patient was more sociable and that he talked with the people in the waiting room before and after the sessions.

Improvement was truly very limited and restricted. The patient began to have more sonorous speech time; however, he was unable to employ the strong voice worked on in therapy into spontaneous speech. It is important to point out that the patient underwent a rapid and progressive worsening in general health during the therapy period.

\section{Patient 04}

The patient was very dedicated and interested throughout the entire therapeutic process and did not demonstrate any difficulty in assimilating the proposed tasks or in performing them in his dayto-day activities. The patient was a member of an evangelical church and his greatest difficulty was to sing. He could no longer reach the different musical notes. His wife accompanied the entire therapeutic process, always seeking different ways to assist him. The patient always showed satisfaction in undergoing vocal treatment, and he affirmed it was easier to speak and to sing.

\section{Patient 05}

The patient demonstrated much interest in going through the therapy because he was having great difficulty in communicating with people. The patient said that over the past few months he did not talk with anyone because people did not have the patience to try to understand him, not even his family, and most especially his wife. This difficulty

\footnotetext{
1. Nos dois casos em que foi necessária a adaptação da técnica de empuxo, a terapeuta se colocava de pé em frente ao paciente sentado e este deveria puxar as mãos da terapeuta em resistência à força aplicada por ela durante os momentos de fonação. Assim, era possível para a terapeuta observar e controlar o esforço exercido pelo paciente.
} 
in communicating with others was one of the primary reasons for his interest in going through therapy. Despite the fact there were serious health problems in the family, he was very interested in his vocal rehabilitation.

The patient sometimes arrived for treatment extremely sad. Nevertheless, he demonstrated great will power to do his best. The thrust technique* was also employed because this patient demonstrated very compromised vocal quality. This facilitated strong voice production. The patient's family did not get involved with the treatment. He informed us that he could not count on help from his wife and children because they were all involved with the family problem. However, he said that his children had told him his voice was easier to understand. The patient demonstrated great satisfaction with the obtained results.

In the two cases where it was necessary to employ the thrust technique, the therapist positioned herself in a standing position in front of the seated patient. The patient was to pull the therapist's hands in resistance to the force being applied during phonation. It was thus possible for the therapist to observe and control the force being employed by the patient.

The results related to the interviews, the evaluations that define the participants in the study and the vocal changes after treatment are shown descriptively.

\section{Results}

Four of the five individuals who participated in this study were male and one was female. The patients ranged in age from 69 to 90 during the study period. The disease manifested itself in these subjects between the ages of 56 and 64 .

All five patients had tremor, akinesia and bradykinesia symptoms, and only two had rigidity.

Questionnaires were used to show that all patients complained of difficulty in pronouncing words and at times they had jumbled and rapid speech. All affirmed they had communication difficulties and said that people always asked them to repeat what they had said. Most of the patients reported a decrease in conversation time after the onslaught of Parkinson's disease. Everyone noticed voice weakening and hoarseness, as well as a reduction in speech speed.

The patients also complained of sialorrhea and said that the amount of time spent during meals increased and the quantity of food decreased after the onslaught of Parkinson's disease. Two patients said they had the sensation that food stopped in their throats.

The tonal audiological evaluation results of the patients with Parkinson's disease are shown in Table 01.

Table 2 refers to the videonasoendoscopy exam results of the glottic region. Laryngeal exams indicate the occurrence of supraglottic constriction. This is antero-posterior in two cases and medial in three. The presence of vocal process saliences was also detected, generally accompanied by arching.

The tremor observed in the patients' laryngeal regions was associated with the moments when the upper member's tremors were most intense.

The results of the perceptive evaluation of the voice for the five patients with Parkinson's disease are shown in Table 3 with regard to voice type and in Table 4 with regard to maximum phonation time. These evaluations were carried out both pre- and post vocal treatment. Reduced loudness was demonstrated by most patients. Speech intelligibility was jeopardized in the pre-treatment period. After the Lee Silverman voice therapy, vocal quality alterations were reduced or even eliminated in all of the patients (Table 3 ). They also demonstrated improved loudness, intonation and articulation (Table 5), as well as increased average intensity (Table 5, Graph 1).

It is important to point out that patients 02 and 04 demonstrated normal loudness prior to vocal treatment. Their auditory thresholds were also within normal standards. Although the number of patients evaluated in this study may be small, this finding may raise the possibility that auditory acuteness can be a contributing factor to reduced loudness, although the most relevant factor for reduced vocal intensity is the disease's characteristics. In order to confirm this supposition, it would be necessary to evaluate a larger group of patients and relate loudness and auditory acuteness.

Habitual sustained emission intensity averages showing strong and weak intensities in the preand post treatment periods are shown in Graph 2. The increase in intensity for the habitual sustained emission was approximately $10.4 \mathrm{~dB}$.

The results from the questionnaire given to the patients at the conclusion of treatment (Tables 6 and 7) show an improvement in communication effectiveness. 
TABLE 1. Preliminary tonal audiological evaluation results of the 5 patients with Parkinson's disease.

\begin{tabular}{|c|c|c|c|c|c|c|c|c|c|c|}
\hline & \multicolumn{2}{|c|}{ Paciente 1} & \multicolumn{2}{|c|}{ Paciente 2} & \multicolumn{2}{|c|}{ Paciente 3} & \multicolumn{2}{|c|}{ Paciente 4} & \multicolumn{2}{|c|}{ Paciente 5} \\
\hline & OD & $\mathrm{OE}$ & OD & $\mathrm{OE}$ & OD & $\mathrm{OE}$ & OD & $\mathrm{OE}$ & OD & $\mathrm{OE}$ \\
\hline neurossensorial leve & $\mathrm{x}$ & $\mathrm{x}$ & & & $\mathrm{x}$ & $\mathrm{x}$ & & & & $\mathrm{x}$ \\
\hline neurossensorial moderada & $\mathrm{x}$ & $\mathrm{x}$ & & & & $\mathrm{x}$ & & & & $\mathrm{x}$ \\
\hline neurossensorial severa & & & & & & & & & $\mathrm{x}$ & $\mathrm{x}$ \\
\hline neurossensorial profunda & & & & & & & & & $\mathrm{x}$ & $\mathrm{x}$ \\
\hline padrões normais & & & $\mathrm{x}$ & $\mathrm{x}$ & & & $\mathrm{x}$ & $\mathrm{x}$ & & \\
\hline
\end{tabular}

Legenda: $\mathrm{OD}=$ orelha direita; $\mathrm{OE}=$ orelha esquerda.

TABLE 2. Videonasoendoscopy exam results of the 5 patients with Parkinson's disease.

\begin{tabular}{c|cc|cc|c} 
& Paciente 1 & Paciente 2 & Paciente 3 & Paciente 4 & Paciente 5 \\
constrição ântero-posterior & grau 2-3 & ausente & ausente & grau 1 & ausente \\
constrição mediana & D e E fonação & ausente & D e E fonação & D e E fonação & ausente \\
arqueamento & D e E & D & D e E & ausente & D e E \\
processos vocais salientes & ausente & D & D e E & ausente & D e E \\
fechamento glótico & $\begin{array}{c}\text { fenda fusiforme } \\
\text { membranácea total }\end{array}$ & completo & fenda fusiforme & fenda fusiforme & fenda fusiforme \\
& membranácea total & membranácea total & membranácea total
\end{tabular}

Legenda: $\mathrm{D}$ = direita; $\mathrm{E}=$ esquerda.

TABLE 3. Vocal evaluation results for the 5 patients with Parkinson's disease with regard to voice type both pre- and post vocal treatment.

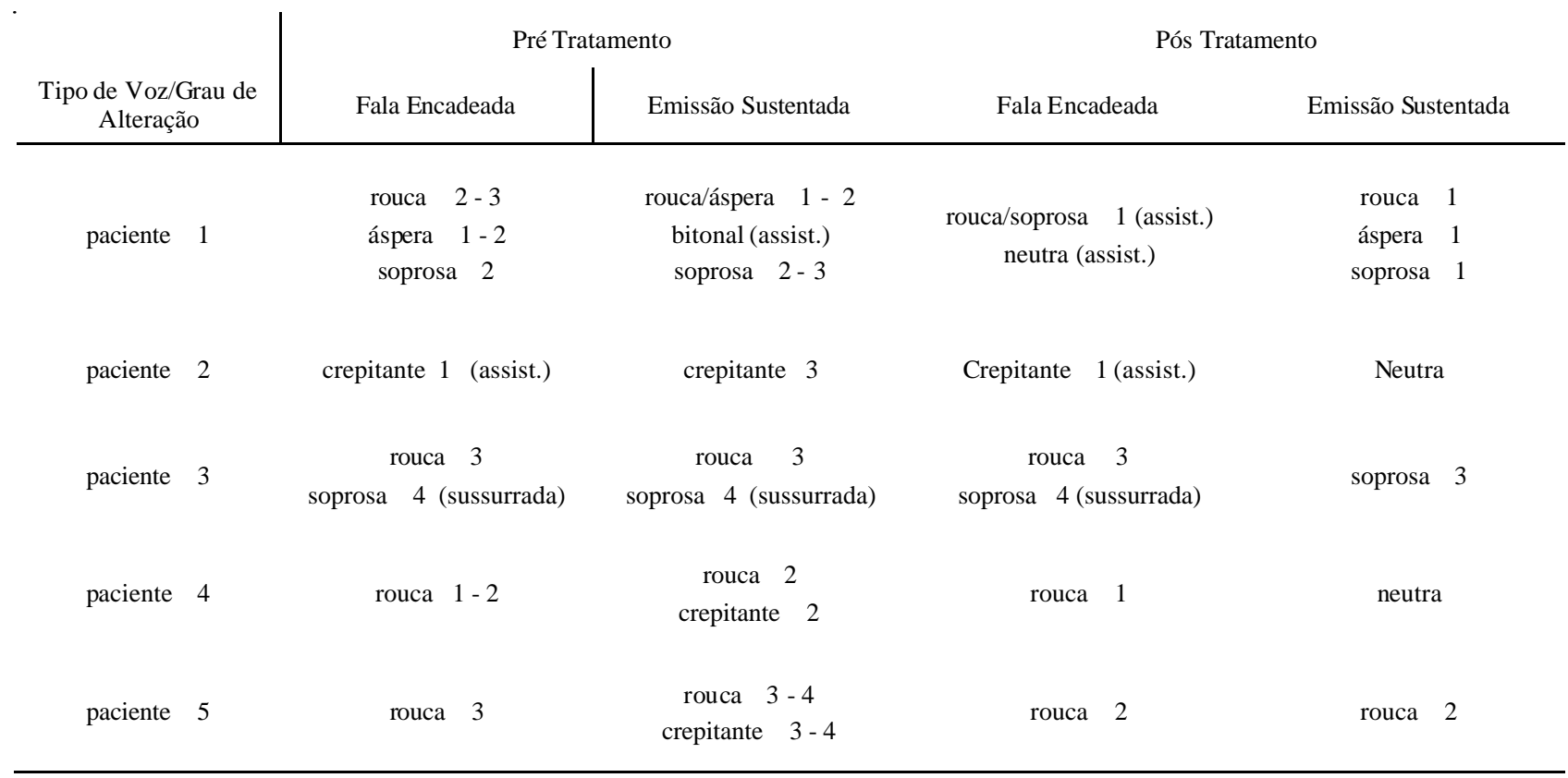


TABLE 4. Vocal evaluation results for the 5 patients with Parkinson's disease, with regard to maximum phonation time.

TMF

paciente 1

paciente 2

paciente 3

paciente 4

paciente 5
Pré Tratamento

$|s /: 7 " \quad| z \mid: 6 "$

$/ \mathrm{s} /:$ 3"

$|z|: 4 "$

s/z: 1,16

|z|: 5"

s/z: 0,75

/a/: 9"

s/z: 1,4

/a/: 8"

/s/: 7"

$|z|: 8 "$

s/z: 0,87

/z/: 7"

s/z: $1 \quad / a /: 15 "$

$/ \mathrm{s} /:$ 7"

/a/: 4"

/a/: 5"

/a/: 15 "

/a/: 15 "

Pós Tratamento

TABLE 5. Pre-and post vocal treatment loudness, intonation and articulatory type evaluation results for the 5 patients with Parkinson's disease.

\section{Loudness}

paciente 1

paciente 2

paciente 3

paciente 4

paciente 5
Pré

fraco

normal

fraquíssimo

normal

fraco

Pós

\section{Pós}

normal

normal

fraco

normal

normal
Gama Tonal

Pós

normal

normal

reduzida

normal

normal
$/ \mathrm{s} /:$ 7"

/s/: $6 "$

$|z|:$ 9"

/s/: 5"

|z/: 8"

s/z: 1,28

s/z: 0,75

/s/: 7"

$|z|: 5^{\prime \prime}$

|z|: 8"

s/z: não aval

|z/: $11 "$

z: 0,87

s/z: 0,81

TABLE 6. Results of the questionnaire given after treatment to the 5 patients with Parkinson's disease with regard to speech and voice.

\begin{tabular}{|c|c|c|c|c|c|}
\hline & Paciente 1 & Paciente 2 & Paciente 3 & Paciente 4 & Paciente 5 \\
\hline notou mudanças na fala/voz & $\operatorname{sim}$ & $\operatorname{sim}$ & $\operatorname{sim}$ & $\operatorname{sim}$ & $\operatorname{sim}$ \\
\hline comentam que estão entendendo sua fala & $\operatorname{sim}$ & $\operatorname{sim}$ & $\operatorname{sim}$ & $\operatorname{sim}$ & $\operatorname{sim}$ \\
\hline pedem pra você repetir & raramente & raramente & quase sempre & nunca & raramente \\
\hline têm dificuldade para entender você & nunca & nunca & quase sempre & raramente & raramente \\
\hline está falando por mais tempo & $\operatorname{sim}$ & $\operatorname{sim}$ & $\operatorname{sim}$ & $\operatorname{sim}$ & não \\
\hline tem praticado os exercícios em casa & $\operatorname{sim}$ & $\operatorname{sim}$ & $\operatorname{sim}$ & $\operatorname{sim}$ & $\operatorname{sim}$ \\
\hline
\end{tabular}

TABLE 7. Comparison of answers from patients with Parkinson's concerning two questions asked pre- and post treatment.

As Pessoas Pedem para Você Repetir

\begin{tabular}{ccccc} 
& Pré-Tratamento & Pós-Tratamento & Pré-Tratamento & Pós-Tratamento \\
paciente 1 & quase sempre & raramente & quase sempre & nunca \\
paciente 2 & sempre & raramente & sempre & nunca \\
paciente 3 & sempre & quase sempre & sempre & quase sempre \\
paciente 4 & quase sempre & nunca & quase sempre & raramente \\
paciente 5 & sempre & raramente & raramente & raramente \\
\hline
\end{tabular}


GRAPH 1. Normal average intensity results in dB during sustained /a/ vowel emission in the 5 patients with Parkinson's disease, pre- and post vocal treatment.

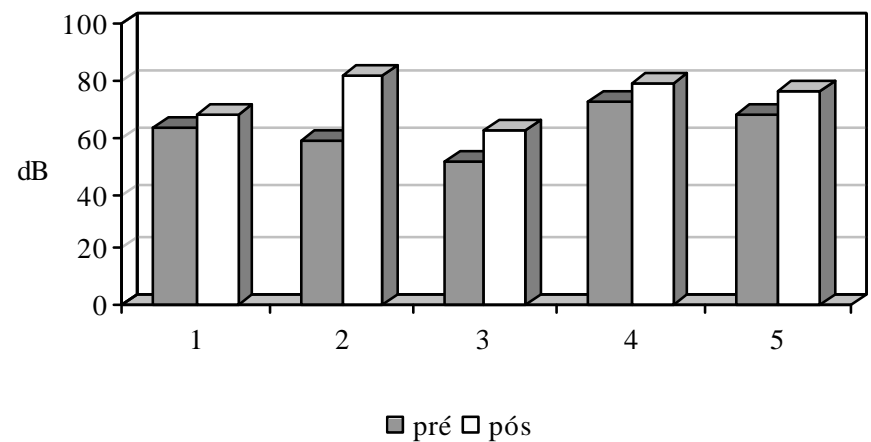

GRAPH 2. Average sustained emission intensity results in $\mathrm{dB}$ for the 05 patients with Parkinson's disease at habitual, strong and weak levels, both pre- and post treatment.

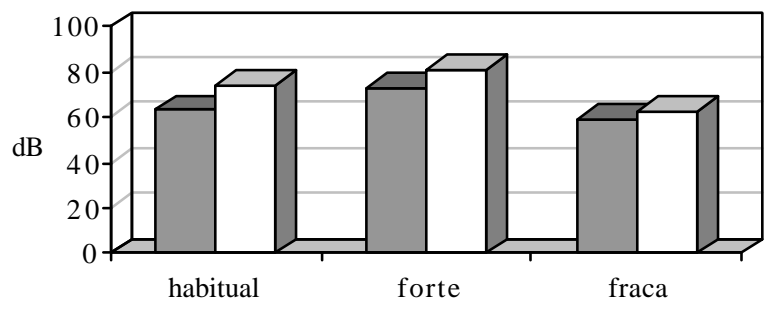

$\square$ pré $\square$ pós

\section{Discussion}

Just as in this study, literature points to a slight predominance of Parkinson's disease in males. It affects all races equally, and the disease normally manifests itself between the ages of 60 and 85 , with 65 years of age being an approximate average (Rapujat et al., 1984).

The symptoms presented by the patients are reported in the literature as being the most common in patients with Parkinson's disease (Swinburn and Morley, 1997). Parkinson's causes progressive and slow rigidity of members, torso and face, and constant and rapid tremors of the hands, and in a lesser degree, the arms and legs. These symptoms are the result of Parkinson's disease being a chronic and progressive degenerative disorder of the central nervous system, jeopardizing basal ganglion functions, especially black substance (Forrest et al., 1989).

All patients complained of difficulty in pronouncing words and of jumbled speech. They said they had difficulty in communicating (Spielman et al., 2003; Oliveira et al., 2004). The speech alterations are the result of jeopardized basal ganglion functions (Forrest et al., 1989). According to Solomon and Hixon (1993), the vocal alterations are caused by incomplete glottic closure, the reduction in laryngeal muscle activation and synergy, muscle fatigue or atrophy, vocal fold movement or tension asymmetry, vocal fold rigidity or respiratory muscle rigidity. The data found show that Parkinson's disease affects the patients' speech intelligibility and vocal communication, as well as their social and psychological well-being (Ramig et al., 2001a).

Dysphagia is one of the results of Parkinson's disease (Schindler and Kelly, 2002; Volonte et al., 2002). Symptoms such as excessive salivation, food or liquid escaping from the mouth, difficulty in opening the mandible, slow mastication, difficulty in initiating swallowing and in moving food from the front of the mouth to the back, the sensation of food being stuck in the throat, coughing or choking during meals, a wet voice soon after eating or drinking, long meal times, difficulty in eating certain kinds of foods and loss of appetite are all reported in literature and occur as the disease progresses (Swinburn and Morley, 1997; Cardoso, 2003). 
As shown in this study, Soares (1999) verified the predominance of descending neurosensorial hearing loss in a population of 21 patients with Parkinson's disease.

With regard to the results obtained from the videonasoendoscopy exam of the glottic region, the literature points in general to laryngeal characteristics of incomplete glottic closure and arching of vocal fold, in cases of Parkinson's disease (Perez et al., 1996; Behlau et al. 2001; Yuceturk et al., 2002). Besides the above-mentioned characteristics, this study also observed the presence of vocal process saliences, generally accompanied by arching, and the occurrence of medial and antero-posterior supraglottic constriction.

Perez et al. (1996) observed that $35 \%$ of a total of 22 patients had laryngeal tremors during rest, $71 \%$ had them during speech at habitual intensities and frequencies and $57 \%$ had them during strong intensity emissions.

The results of the perceptive evaluation of the voice carried out pre- and post vocal treatment in the five patients with Parkinson's disease agree with the data found by Holmes et al. (2000) and Baumgartner et al. (2001). Reduced loudness with jeopardized speech intelligibility at pre-treatment was found in most patients, as was also observed by Dromey et al. (1995); Ramig et al. (1995); Carrarade-Angelis (2000); Holmes et al. (2000); Kleinow et al. (2001); Ramig et al. (2001a; b); Sharkawi et al. (2002). These characteristics fit the generalized bradykinesia context (Gamboa et al., 2001).

The patients showed an improvement in vocal quality, loudness, tonal range and articulation, as well as an increase in average intensity in this study. These findings are consistent with previously reported data (Dromey et al., 1995; Baumgartner et al., 2001; Sapir et al., 2002), reinforcing LSVT ${ }^{\circledR}$ effectiveness in treating phonatory alterations associated with Parkinson's disease.

In their case study, Dromey et al. (1995) observed a $20 \mathrm{~dB}$ increase in sustained vowel emissions in their patient after treatment. Ramig et al. (1995) found a $68.4 \mathrm{~dB}$ average intensity in their study for sustained emission during pre-treatment and an $82.4 \mathrm{~dB}$ average during post treatment. In yet another study, an increase of approximately $15 \mathrm{~dB}$ was found in sustained vowel emissions at habitual intensities pre- and post treatment (Ramig et al., 2001b).

Ramig et al. (1995) observed improved communication effectiveness for patients with Parkinson's disease after vocal treatment using the
Lee Silverman method. This is same result observed in this study.

Although there are already many studies that demonstrate the effectiveness of the LSVT ${ }^{\circledR}$ method and the results obtained pre- and post vocal treatment, in clinical practice we see that there are aspects that facilitate this population's vocal rehabilitation and others that make it difficult, especially when employing LSVT ${ }^{\circledR}$.

Through the analysis of each individual's interfering factors it was possible to list the aspects that contributed and that hampered the vocal treatment process, relating them to the obtained results. We believe these factors should be taken into consideration in the rehabilitation process of patients with Parkinson's disease in order to obtain effective results.

\section{Conclusion}

We observed aspects in this study that contributed to successful treatment: patient interest in voice rehabilitation, as well as family participation and an active social life, served as encouragement. However, some factors made it impossible to achieve the patient's best potential: fixed schedules were not possible because of each patient's activities, limited health conditions, sad emotional state, depression and a lack of discipline in carrying out the proposed activities to be performed at home.

After the treatment period for the five patients with Parkinson's disease, it was possible to observe an improvement in vocal quality parameters, articulation and a general increase in vocal intensity for speech. This improvement resulted in greater oral communication suitability for the subjects, which in turn generated greater satisfaction in the patients as well as their families.

\section{References}

BAUMGARTNER, C. A.; SAPIR, S.; RAMIG, L. O. Voice quality following phonatory-respiratory effort treatment (LSVT ${ }^{\circledR}$ ) versus respiratory effort treatment for individuals with Parkinson disease. J. Voice, v. 15, n. 1, p. 105-114, 2001. BEHLAU, M.; AZEVEDO, R.; PONTES, P.; BRASIL, O. Disfonias funcionais. In: BEHLAU, M. Voz o livro do especialista. Rio de Janeiro: Revinter, 2001. v. 1, cap. 4, p. 247-293.

CARDOSO, M. C. A. F.; GOULART, A. P. F.; MARQUES, D. F.; MORISSO, M. F.; OLIVEIRA, P. P. Xerostomia: sensação ou hipoprodução das glândulas salivares? Pró-Fono Revistade Atualização Científica, v. 14, n. 3, p. 325-330, 2002. 
CARDOSO, M. C. A. F. A aplicabilidade de técnicas vocais em casos de disfagia orofaríngea. Pró-Fono Revista de Atualização Científica, v. 15, n. 2, p. 125-138, 2003.

CARRARA-DE-ANGELIS, E. Deglutição, configuração laríngea, análise clínica e acústica computadorizada da voz de pacientes com doença de Parkinson. 2000. $144 \mathrm{f}$. Tese (Doutorado em Fonoaudiologia) - Universidade Federal de Säo Paulo. Escola Paulista de Medicina, São Paulo.

DROMEY, C.; RAMIG, L. O.; JOHNSON, A. B. Phonatory and articulatory changes associated with increased vocal intensity in Parkinson disease: a case study. J. Speech Lang. Hear Res., v. 38, n. 4, p. 751-764, aug. 1995.

FORREST, K.; WEISMER, G.; TURNER, G. S. Kinematic, acoustic and perceptual analyses of connected speech produced by parkinsonian and normal geriatric adults. $J$. Acoust. Soc. Am., v. 85, n. 6, p. 2608-2022, Jun. 1989.

GAMBOA, J.; JIMÉNEZ-JIMÉNEZ, F. J.; MATE, M. A.; COBETA, I. Alteraciones de la voz causadas por enfermedades neurológicas. Rev. Neurol., v. 33, n. 2, p. 153-168, 2001 .

HOLMES, R. J.; OATES, J. M.; PHYLAND, D. J.; HUGHES, A. J. Voice characteristics in the progression of Parkinson's disease. Int. J. Lang. Comm. Dis., v. 35, n. 3, p. 407-418, 2000.

KNOOP, D.; PADOVANI, M. Voz, fala e deglutição. In: LIMONGI, J. C. P. Conhecendo melhor a doença de Parkinson. São Paulo: Plexus, 2001. cap. 5, p. 117-135.

KLEINOW, J.; SMITH, A.; RAMIG, L. O. Speech motor stability in IPD: effects of rate and loudness manipulations. J. Speech Lang. Hear Res., v. 44, n. 5, p. 1041-1051, oct. 2001.

LEOPOLD, N. A.; KAGEL, M. C. Pharyngo-esophageal dysphagia in Parkinson's disease. Dysphagia. v. 12, n. 1, p. 11-18, 1997.

MONTE, C. A.; MOURÃO, L. F.; MOTA, P. H. M. Avaliação fonoaudiológica e otorrinolaringológica em idosos pré e pós programa vocal. Pró-Fono Revista de Atualização Científica, v. 13, n. 2, p. 169-176, 2001.

NITRINI, R.; BACHESCHI, L. A. A neurologia que todo médico deve saber. São Paulo: Atheneu, 1991.

OLIVEIRA, C. R.; ORTIZ, K. Z.; VIEIRA, M. M. Disartria: estudo da velocidade de fala. Pró-Fono Revista de Atualização Científica, v. 16, n. 1, p. 39-48. 2004.

PEREZ, K. S.; RAMIG, L. O.; SMITH, M. E.; DROMEY, C. The Parkinson larynx: tremor and videostroboscopic findings. J. Voice., v. 10, n. 4, p. 354-361, 1996.

RAMIG, L. O. COUNTRYMAN, S.; THOMPSON, L.; HORII, Y. Comparasion of two forms of intensive speech treatment for Parkinson disease. J. Speech Lang. Hear. Res., v. 38, n. 6, p. 1232-1251, dec. 1995.
RAMIG, L. O.; SAPIR, S.; COUNTRYMAN, S.; PAWLAS, A. A.; O'BRIEN, C.; HOEHN, M.; THOMPSON, L. L. Intensive voice treatment $\left(\operatorname{LSVT}^{\circledR}\right)$ for patients with Parkinson's disease: a 2 year follow up. J. Neurol. Neurosurg. Psychiatry, v. 71, n. 4, p. 493-498, 2001 a.

RAMIG, L. O.; SAPIR, S.; FOX, C.; COUNTRYMAN, S. Changes in vocal loudness following intensive voice treatment (LSVT ${ }^{\circledR}$ ) in individuals with Parkinson's disease: a comparison with untreated patients and normal age-matched controls. Mov. Disord., v. 16, n. 1, p. 79-83, 2001.

RAJPUT, A. H.; OFFORD, A.P.; BEAR, C. M.; Epidemiology of Parkinson's disease: incidence, classification and mortality. Ann. Neurol., v. 16, p. 78-132, 1984.

REGNELL, M. E. Speech pathology \& Parkinson's disease in the home environment. Caring, v. 22, n. 1, p. 20-22, jan. 2003.

SAPIR, S.; RAMIG, L. O.; HOYT, P.; COUNTRYMAN, S.; O'BRIEN, C.; HOEHN, M. Speech loudness and quality 12 months after intensive voice treatment (LSVT) for Parkinson's disease: a comparison with an alternative speech treatment. Folia Phoniatr Logop., v. 54, n. 6, p. 296-303, nov-dec. 2002.

SCHINDLER, J. S.; KELLY, J. H. Swallowing disorders in the elderly. Laryngoscope, v. 112, n. 4, p. 589-602. apr. 2002.

SHARKAWI, A. E.; RAMIG, L.; LOGEMANN, J. A.; PAULOSKI, B. R.; RADEMAKER, A. W.; SMITH, C. H.; PAWLAS, A.; BAUM, S.; WERNER, C. Swallowing and voice effects of Lee Silverman voice treatment $\left(\mathrm{LSVT}^{\circledR}\right)$ : a pilot study. J. Neurol. Neurosurg. Psychiatry., v. 72, n. 1, p. 31-36, jan. 2002.

SOARES, A. Avaliação fonoaudiológica de pacientes portadores das sindromes parkinsonianas. 1999. Monografia (Iniciação Científica) - USC - Bauru.

SOLOMON, N.; HIXON, T. Speech breathing in Parkinson's disease. J. Speech Hear. Disord., v. 36, p. 294-310, 1993

SPIELMAN, J. L.; BOROD, J. C.; RAMIG, L. O. The effects of intensive voice treatment on facial expressiveness in Parkinson disease: preliminary data. Cogn. Behav. Neurol., v. 16 , n. 3, p. 177-188, sep. 2003.

SWINBURN, K.; MORLEY, R. Parkinson's disease: management pack - clinicians's manual. Tolton, Hampshire, United Kingdom: Hobbs the printers, ltda, 1997.

VOLONTE, M. A.; PORTA, M.; COMI, G. Clinical assessment of dysphagia in early phases of Parkinson's disease. Neurol. Sci., v. 23, n. 3, S121-122, sep. 2002. Suppl 2.

YUCETURK, A. V.; YILMAZ, H.; EGRILMEZ, M.; KARACA, S. Voice analysis and videolaryngostroboscopy in patients with Parkinson's disease. Eur. Arch. Otorhinolaryngol., v. 259, n. 6, p. 290-293. jul. 2002.

Observação: as autoras deste artigo são certificadas a aplicar o método Lee Silverman Voice Treatment (LSVT ${ }^{\circledR}$ ) pela Ellis Neurological Foundation.

Endereço para correspondência:

Denise Navarro Silveira

R. Salinas, 263 - Cel. Fabriciano - MG - CEP: 35170-132. 